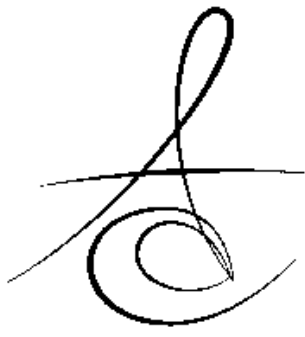

\section{TEMPOROMANDİBULAR EKLEM TAMİR VE REJENERASYONUNDA DOKU MÜHENDİSLİĞİ UYGULAMALARI}

\section{TISSUE ENGINEERING APPLICATIONS FOR TEMPOROMANDIBULAR JOINT REPAIR AND REJENERATION}

\author{
Doç. Dr. Perihan OYAR ${ }^{*}$
}

\section{öz}

Temporomandibular eklem (TME) hastalıkları eklem içi pozisyonel ve/veya yapısal bozukluklarla karakterizedir. En sık rastlanan TME hastalıkları arasında TME in artiküler diskinin yer değiştirmesi gelir. Kök hücre kaynaklı tedavilerin gelişmesindeki ilerlemeler TME tamir ve rejenerasyonu konusunda önemli bir role sahiptir ve TME rahatsızlıklarının tedavisinde alternatif bir metot sunabilir. Bu derlemenin amacı TME hastalıklarında disk ve kondilin tamiri ve/veya yeniden yapılandırılmasında kök hücre ve doku mühendisliği uygulamaları ile ilgili gelişmeleri sunmaktır.

Anahtar kelimeler: Temporomandibular eklem, Doku mühendisliği, Kök hücre

\title{
ABSTRACT
}

The application of low-intensity ultrasound is a TMJ disorders are characterized by intra-articular positional and/or structural abnormalities. The most common type of TMJ disorders involves displacement of the TMJ articular disc. The development of stem cell based therapies and tissue engineering have an important role in the repair and regeneration of TMJ, and have provided alternative methods to in the treatment of TMJ disorders. This review discusses the most recent advances in development of stem cellbased treatments for TMJ disorders. The purpose of this review is to provide a summary of advances relevant to tissue engineering and stem cell applicatios for repairing and/or replacing the mandibular condyle and disc in the TME disorders.

Keywords: Temporomandibular joint, Tissue engineering, Stem cell,

\section{Temporomandibular Eklem}

Temporomandibular eklemin (TME) artiküler diski, kan damarları ve sinir fibrilleri içermeyen yoğun fibröz konnektif dokudan oluşan bir yapıdadır. Artiküler kıkırdak ise kan damarları ve sinirlerden yoksundur. 1,2 Bu yüzden sınırlı tamir yeteneğinden dolayı tedavisi en zor dokulardan birsidir. TME nin artiküler kıkırdağı fibrokartlaj yüzey tabakası ve ince bir intermediat proliferatif zone a sahiptir. 3. TME hastalıklarının etyolojisi ve hastalığın ilerleyişi sıklıkla maksillofacial travma, eklemin aşırı yüklenmesi, maloklüzyonlar, stres ve psikiyatrik hastalıkları içeren faktörlere bağlı olmasına karşın hala tam olarak anlaşılamamıştır. ${ }^{4-6}$

TME rahatsızlıklarının etyolojisi multifaktöriyel olduğu için tedavisinde farklı yöntemlerin kombine kullanıldığı yaklaşımlar bulunmaktadır. Konservatif tedaviler yetersiz kaldığında cerrahi tedaviler tercih edilmektedir. $^{7}$ Nonsteroid antienflamatuarlar ve analjezikler sıklıkla tedavi için verilir. Bu ajanlar yalnızca semptomlara yöneliktir ve osteoartiritin ilerleyişi için başarılı olamaz. Genellikle, farmokolojik terapiler ağrının azalması için yetersiz kalır. ${ }^{8}$ Minimal invaziv yaklaşımlar tavsiye edilmiştir ve hyaluronik asit gibi ajanların kullanımı tartışmalıdır ve tutarsız sonuçlar yaratır. ${ }^{9}$ Bilindiği üzere, otojenik hücreler doku rejenerasyonu için kullanılan standart hücre kaynağıdırlar, fakat bunların TME de zarar görmüş hücreler üzerinde etkili olması çok zor olabilir. Bu nedenle tedavide etkili olabilecek diğer hücre kaynaklarının yani kök hücrelerin böyle vakaların tedavisi için bir alternatif

*Hacettepe Üniversitesi, Sağlık Hizmetleri Meslek Yüksek Okulu, Diş-Protez Teknolojisi Programı 
olabileceği belirtilmiştir. ${ }^{10-12}$ Kemik ve kıkırdak rejenerasyonları için, in vitro büyüyen bir bifazik osteokondral yapı oluşturmak çok zordur. ${ }^{3}$ Kıkırdak dokunun rejenerasyon yeteneğinin kısıtlı olması araştırmacıları doku mühendisliği ile kıkırdak üretimine yöneltmiştir.

\section{TME Diski Ve Doku Mühendisliği}

TME diski doku mühendisliğinde dizaynlama TME nin hücresel, biyokimyasal ve mekanik özelliklerini geniş biçimde anlamamıza bağlıdır. Doku mühendisliği stratejileri doğal TME diskini oluşturmayı deneyerek tipik olarak 3 komponentli yaklaşım sunar. Bunlar; hücre kaynağı, yapı iskelesi için biyomateryaller ve matriks depozisyonu ve hücre büyümesi için biyokimyasal ve/veya biyomekaniksel stimülasyondur. ${ }^{13}$ TME disk nin doku mühendisliği 1990 dan bu yana, bilim adamları tarafından üzerinde çalışılan bir konudur. TME disk mühendisliği ile ilgili ilk çalışmalar tip 1 mesh kollojeni kullanılarak yapıldı, extrasellüler matriks TME disk rekonstrüksiyonu için ideal yapı iskelesi materyali olarak görünür. ${ }^{14} 1994$ yılında Puelacher ve ark. ${ }^{15}$ biyobozunur poliglikolik asit (PGA) ve polilaktik asit (PLA) fiberlerini kullandılar. Bu başlangıç girişimleri TME disk mühendisliğinin uygulanabilirliliğini gösterdi. On yılı aşkın süredir çalışmalar TME diski doku mühendisliğinin temel elemanlarını olan yapı iskeleleri, hücre kaynakları, biyolojik/ biyokimyasal stimülasyon üzerinde sürdürülmektedir.

\section{Doku Mühendisliğinde TME Diski İçin Kullanılan Hücre Kaynakları}

Doku mühendisliği için ideal hücre kaynakları bol, ulaşılabilir, sağlam olmalıdır. Alternatif kaynak seçiminde hedef hücrelerin fonksiyonelliğinin düşünülmesi gereklidir. Elde edilecek olan TME diski hem fibröz doku hem de kıkırdak doku özelliğine sahip olmalıdır. $^{16}$

\section{Doğal TME Diskinden Otolog Hücreler}

TME diski doku mühendisliği için daha önceki çalışmalar sıklıkla TME disk hücreleri için yapıldı. ${ }^{14,17-22}$ Çok sayıda girişimlere rağmen, bu hücreler bir doku oluşumu ve fonksiyonu için henüz gerekli mekanik dayanıklılık veya biyokimyasal içeriğe sahip değildirler. Kullanılan TME disk hücreleri sağlıklı hücrelerin son derece sınırlı sayısı, bunların kültüre edilmesi ve saklanması, ve yeterli in-vitro matriks üretim yetersizliği gibi dezavantajlara sahiptir. ${ }^{23}$
Bazı araştırmacılar disk hücrelerinin ekimini takiben hücre sayısının fazlasıyla azaldığı, yeterli morfolojiyi elde etmek için yapının büzüldüğü ve başarısız olduğu ${ }^{24}$ ve TME disk hücrelerinin kültür edilmesi işlemi boyunca bunların fenotiplerinin değişmesine eğilimli olduğunun gözlemlenmesi nedeniyle TME disk hücrelerinin doku mühendisliğinde kullanılmasının uygun bir seçim olmadığını belirtmişlerdir. ${ }^{17-}$ 25,26 Yaşlanma ve dejeneratif işlemler boyunca TME diskinde hem morfolojik, hem de hücresel değişiklikler görüldüğü için doku mühendisliğinde bu hücrelerin performansı tahmin edilemez. ${ }^{27}$ Bu sebeplerden dolayı çalışmaların sayısı artmış ve diğer potansiyel hücre kaynakları araştırılmaya başlanmıştır.

\section{Kıkırdak veya Artiküler Dokular}

Yüksek hücre tutulumu, ekstrasellüler matriks üretimi ve klinik olarak ilgili boyutlarda doku üretebilme yeteneği ile kostal kondrositlerin gelecekte TME doku mühendisliğinde hücre kaynağı olarak kullanılma intimalinin yüksek olduğu düşünülür. ${ }^{28}$ Kostal kondrositler ve karma yapıların morfolojik ve biyokimyasal olarak diğer yapılara göre üstün olduğu gösterilmesine rağmen doku aşırı büyümesi, arzu edilmeyen kalsifikasyonlar ${ }^{28}$; kollojen içerik ve mekanik özelliklerin geliştirilmesine intiyaç duyulması gibi bazı dezavantajları ve komplikasyonları vardır. ${ }^{28,23,24}$

\section{Kök Hücreler}

Son zamanlarda TME diski ve kıkırdak doku mühendisliği için ümit vaad eden diğer bir hücre kaynağı olarak kök hücre kullanımına artan bir ilgi olmuştur. $^{29-35}$ Kök hücreler geniş bir sağlıklı hücre populasyonu ve sayısız tipte dokular üretmek için farklılaşan ve yaygın bir şekilde çoğalma potansiyeline sahip hücrelerdir. Embriyonik kaynaklar' deri, yağ, kemik iliği göbek bağı kordon kanı ve sinoviyal membran ${ }^{40,41}$ hücrelerinin fibrokondrositler veya kondrositlere dönüşme kapasitesi olduğu gösterilmiştir. ${ }^{28-39}$ Fakat, uygun bir fenotipe farklılaşan kök hücreler oldukça kompleks olabilirler, ciddi zorluklar ortaya çıkarabilirler ve fibrokondrosit benzeri hücreleri üretmek için en iyi statejinin ne olduğu hala açık değildir. ${ }^{42}$ Yüksek hücre yoğunluğu, uygun büyüme faktörleri ve mekanoindüktif bir çevre kullanarak fibrokondrosit benzeri hücreler üretmek için şimdi kullanılan metot kültür ortamlarında modifiye etmektir. Fakat, büyüme faktörleri ${ }^{36,34}$ mekanik stimülasyon ve hipoksi dahil 
fibrokondrosit farklılaşması ve matriks üretimi için uygun ve yeterli stimülasyonun ne olduğu henüz bilinmiyor. ${ }^{43,44}$ Kök hücreler TME in rejenerasyonu ve tamiri için ümit vaad eden bir hücre kaynağı sunar ve 2 majör kaynaktan elde edilebilir: mezenkimal kök hücreler ve embriyonik kök hücreler. ${ }^{\mathbf{3 0 4 0 , 4 5}}$ Bunların kendini yenileme ve farklılaşma potansiyeleri vardır.

\section{İnsan embriyonik kök hücreler}

İnsan embriyonik kök hücreleri rejeneratif uygulamalarda yüksek potansiyele sahiptir ve bunların fibrokartilaj doku mühendisliği için gelişmekte olan hücre kaynağı olarak kullanılabileceği gösterilmiştir. $^{36,37,45}$ Bu hücre kaynağının kullanıldığı TME diski doku mühendisliğindeki girişimler hala başlangıç aşamasındadır. Bu yöndeki önemli bir adım Hoben ve ark. $^{36}$ tarafından yapılmıştır, fibrokondrosit benzeri hücreler içinde insan embriyonik kök hücrelerin farklılaşma potansiyelini araştırmışlar ve fibrokartilaj doku mühendisliği için insan embriyonik kök hücrelerinin uygunluğunu ve insan embriyonik kök hücre kaynaklı fibrokartilaj yaratmak için stratejiler belirlemişlerdir.

\section{Mezenkimal kök hücreler}

Kartilaj tamiri ve doku mühendisliği için rapor edilen pek çok kök hücre kaynakları arasında mezenkimal kök hücreler; kolay ede edilebilir olması, otolog mezenkimal kök hücre transplantasyonuna karşı allergenik reaksiyonlara sebep olmaması nedeniyle en yaygın şekilde kullanılan kök hücre kaynaklarıdır. Kemik iliğ ${ }^{46,47}$, kas $^{48}$, deri ${ }^{49}$, yağ dokusu ${ }^{50}$, kan ${ }^{\mathbf{5 1}}$, dental pulpa, göbek kordon kanı, plasenta ve son zamanlarda sinovium ${ }^{52}$ ve TME nin sinovial sIVISIndan ${ }^{53}$ izole edilmiştir. TME den izole edilen mezenkimal kök hücrelerin TME kartilaj ve subkondral kemiğin tamir ve rejenerasyonundaki etkileri gösterilmiştir. Bu hücreler fibroblast benzeri, iğ şekilli morfolojiye sahiptirler ve uygun in vitro kültür ortamında yağ dokusu, nörojenik, kondrojenik ve osteojenik farklılaşma yeteneğine sahiptirler. Adult mezenkimal kök hücreler arasında, sinovium kaynaklı mezenkimal kök hücreler TME tamir ve rejenerasyonunda kondrositlerin proliferasyonu ve farklılaşmasında üstünlük sergilerler. Kondrosit üretiminde mezenkimal kök hücre kullanımının başıca dezavantajları ise hücreler genişler ve farklı gelişimsel basamakları takiben farklılaşıllar fakat bunlar artiküler kondrositlerde olduğu gibi prehipertrofik aşamada durmazlar. ${ }^{53-56}$ Son yllarda, TME tamir ve rejenerasyonunda mezenkimal kök hücrelerin uygulanmasına ilgi artmıştır. Wu ve $\operatorname{ark}^{40}$ TME diskinin tamirinde TME kaynaklı sinovial mezenkimal kök hücrenin kullanımını göstermişlerdir.

\section{Diğer Yetişkin Kök Hücreler}

Bir fibrokondrosit hücre populasyonu fibroblastik hücreden elde edilebilir. Dermal fibroblastlar yağ, osteojenik ve kondrogenik hücrelerden farklılaşabilir. Dermal fibroblastlar doğal olarak fibrojenik olmasına rağmen kondrojenik potansiyele sahiptir. ${ }^{57}$ İlave olarak dermal fibroblastlar kolayca saklanabilir ve TME disk hücrelerinden daha boldur.45. Otolog hücrelerin kullanımı immun cevabın değişmesini büyük oranda azaltmışıır. Tüm bu özellikler bunların TME doku mühendisliği için klinik olarak uygun hücre kaynakları olduğunu gösterir. ${ }^{29}$ Mezenkimal orijinlerden dolayı yağ kök hücreleri hem kondrojenik hem de fibroblastik farklılaşma kapasitesine sahiptir ve TME disk doku mühendisliği için iyi bir alternatif olarak hizmet ederler. ${ }^{58}$

\section{Doku Kaynaklı Materyaller}

Doğal kaynaklardan elde edilen materyaller extraselluler matriks ve özgün komponentleri içerir. Ekstrasellüler matriks yapı iskeleleri doğal matriksten elde edilen materyallerdir, bu yüzden bunlar doğal ortam sağlayabilirler. TME disk doku mühendisliğinde kollogen ${ }^{14}$, fibrin ${ }^{23}$, alginate ${ }^{19}$ ve kitozan gibi özel bileşenler kullanılır. Doku kaynaklı yapı iskelesi materyalleri doğal bir materyal olarak, son zamanlarda TME diski mühendisliğindeki uygulanabilirliliği araştırılmaktadır. ${ }^{59,60} \mathrm{Bu}$ araştırmalarda doku kaynaklı biyo yapı iskeleleri TME nin yerine kullanılması için iyi bir çözüm sunabilir. Kollogen en çok bulunan ekstraselluler matriks komponentidir, yapımı kolaydır ve dayanımı sentetik yapı iskelelerine benzerdir. TME disk rekonstrüksiyonu için kollojenin ideal bir yapı iskelesi materyali olduğu gösterilmiştir. ${ }^{14}$

Fibrin ideal bir yapı iskelesidir, hücre proliferasyonu destekler ve ektraselluler matriks üretimini destekler. Fakat bunun gel oluşumu sırasında büzülmesi, zayıf mekanik dayanımı ve hızı bozunması gibi yapı içi özellikleri nedeniyle bunun bağımsız olarak kullanılabilmesini kısıtlayabilir. ${ }^{23}$

Doğal kitozan bir polisakkarit materyaldir, bunun porlu yapısı iyi biyouyumluluk sağlar, mekanik

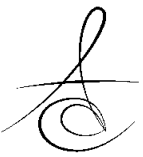


dayanım ve kültüre edilmesi boyunca şeklinin bozulmasını sağlar. Yapı iskelesi materyaller hidrojeller, fibröz örgüler ve süngerler olarak katagorize edilebilirler. Ne yazık ki TME disk hücresi için yapı iskelesi olarak hidrojellerin iyi bir çözüm olmadığı görülmüştür. ${ }^{61}$

\section{Yapı İskeleleri}

TME disk mühendisliği için ideal yapı iskelesi geri dönüşebilir olmalııı, besinlerin hücrelere girişine izin vermek için yeterli oranda porlu yapıda olmalıdır, matriks depozisyonunu desteklemelidir ve rejenerasyon işlemleri boyunca yeterli mekanik destek sağlamalıdır. Şimdiye kadar TME diskinde kullanılan yapı iskeleleri doğal materyallerden elde edilen ve sentetik polimerler olmak üzere iki sınıfta katagorize edilebilirler. Bu materyaller arasında hibritler ve kompozitler de vardır. ${ }^{62}$ Uygun yapı iskelelerinin seçimi doku mühendisliğinde önemli bir adımdır. Biyomateryal sacffold matriks depozisyonu, yeni doku oluşumu, hücresel büyümeye yapısal destek sağlamada önemli rollere sahiptir. Doku remodellingine izin vermek için bizobozunur olması gerekir ve arzu edilen anatomik şekil ile yeni dokunun gelişmesine fayda sağlamalıdır. ${ }^{63,64}$

\section{Sentetik Polimer Yapı İskeleleri}

Sentetik polimerler yüksek işleme kapasitesi, mekanik stabilite, biyouyumluluk, biyobozunurluluğa sahiptir ve bunlar ile uygun por yapısı, fiber boyutu ve uygun yapı iskelesi geometrisini elde edebilmek kolaydır. TME doku mühendisliğinde başarıla ve en yaygın olarak kullanılan biyomateryaller poli(glikolik asit), poli-L-laktik asit (PLLA) ve poli (gliserol sebacate) (PGS) dir. ${ }^{19,62}$ Bu materyaller arasında, poliglikolik asit TME disk doku mühendisliğinde en yaygın kullanılan biyomateryallerden birisidir. Çünkü biyouyumludur, matriks depozisyonu ve hücre proliferasyonunu sağlar. Fakat hızlı bozunma sergiler, yapısal/mekanik bütünlük kaybıyla sonuçlanır ve zamanla yapısal kontraksiyona uğrar. ${ }^{65}$ PGA TME disk kaynaklı hücreler ile iyi uyuma sahip olmasına rağmen, çoğunlukla hızlı rezorbsiyonlarından dolayı zayıf mekaniksel dayanıklılık gösterirler. ${ }^{19}$ PLLA uzun bozunma zamanına sahiptir bu özellik daha fazla matriks sekresyonuna ve yapının kontraksiyonunun azalmasına izin veriir ${ }^{22}$ ve TME disk mühendisliği için ümit vaad edici olduğu düşünülür. Hagandora ve arkadaşları $^{62}$ TME disk mühendisliği için yeni bir yapı iskelesi materyali olarak PGS kullanmıştır. PGS nin PGA da görülen kontraksiyonu önlediği için TME disk mühendisliğinde kullanılmasında yüksek potansiyele sahip olduğunu belirtmişlerdir.

\section{Yapı İskelesi İçermeyen Sistemler}

Yapı iskelelerinin kullanımı konusunda hücrelerin fenotip alternasyonları, ürünlerin toksik bozunması, enflamasyona cevap, yeni doku oluşumunun engellenmesi ve immun cevap gibi konularda hala bazı sınırlamalar vardır. ${ }^{66}$ Athanasiou ve arkadaşları ${ }^{67}$ bu yapı iskelesi olmayan uygulamayı "Self-assembly" olarak adlandırmışır. Bu yöntemde yeni doku içinde hızı bir şekilde gelişim ve oluşum için yüksek yoğunlukta yapı iskelesi olmayan agara ekim yapılır. Fonksiyonel kıkırdak, fibrokartilaj ve diğer dokuların oluşumu için uygun olduğu görülmüştür. ${ }^{67-70}$ Self-assembly bu yüzden TME disk doku mühendisliği için bir alternatif olabilir ve uygulanabilir, fakat yapı iskelesi olmayan yapıların hücrelerin yaşanabilirliliğini destekleme ve matriks üretimi konusunda yetersiz olduğu görülmüştür. ${ }^{71}$

\section{Sinyaller}

Biyokimyasal ve biyomekaniksel sinyaller hücre metobolik aktivitelerini artırmada bağımsızdırlar ve yapının mekanik özelliklerini artırılar. Biyolojik sinyaller ekstrasellüler matriks protein yapısı içinde kademeli olan yolları aktive edebilir. Büyüme faktörleri doku mühendisliğinde kullanılan en yaygın biyolojik sinyallerdir: askorbik asit, proline (bir çeşit aminoasit), ve glutamin gibi kimyasallar sinyal olarak görev görebilir. Uygun büyüme faktörlerinin salınımı kartilaj rejenerasyonu için gereklidir ${ }^{72}$ Büyüme faktörleri TME disk yapıları üzerinde pozitif etki için yüksek potansiyele sahiptir fakat kültür ortamı ve ekim teknikleri ile ilgili bilgi sınırıdır. ${ }^{73}$ Mekanik stimülasyon metabolik aktiviteleri artırmak için diğer bir basit sinyaldir ve TME disk yapısının mekaniksel özelliklerini etkiler. Biyomekanik stimülasyon matriks üretimi ve hücrenin hayatta kalmasını sürdürebilmesinde esas unsur olabilir. ${ }^{73} \mathrm{Ne}$ yazık ki, şimdiye kadar yalnızca çok az çalışmada TME diski için mekaniksel stimülasyon uygulanmıştır. Çalışmalar hidrostatik baskının ekstrasellüler matriksin spesifik gen aktarımını regüle etmek için farklı kanalların sinyal aktarımını değiştirebildiği ve stimüle edebildiğini ve sonunda extrasellüler matriks sentezini artırabildiğini göstermiştir. ${ }^{74,75}$ Biyokimyasal ve mekanik sinyallerin sinerjik ve ilave etkileri hem fibrokartilaj hem de diğer kıkırdak ile ilgili çalışmalarda gösterilmiştir. ${ }^{76,77,78}$ 


\section{TME Kondil Doku Mühendisliği}

TME kondili ince bir kartilaj tabakası ile çevrili kemiksi bir yapıdır. Bu yüzden mandibular kondilin yapımında, yapı iskelesi dizaynında kıkırdak ve kemiğin farklı gereksinimlerinin de hesaba katılması gerekir. Yapı iskelesi dizaynı üzerinde yapılan erken dönem çalışmalar bifazik yapı iskelelerinin oluşturulması üzerinde yoğunlaşmıştır. 55,155. Diğer çalışmalar osteojenik ve kondrojenik hücrelere farklılaşabilme kapasitesine sahip olan mezenkimal kök hücrelerden kıkırdak ve kemiğin tabakalı yapılarıı kültür ortamında oluşturma konusunda ve yapı iskelesi dizaynı üzerinde yoğunlaşmışıı. ${ }^{79,80}$ Son zamanlarda hyaluronik asit hidrojel yapı iskelesinin matriks sıklığı ve çapraz bağlanma derecesi kondrogenezis sırasında mezenkimal kondenzasyonun boyutunun kontrolüyle kıkırdakj dokunun farklı tiplerinin oluşumunda mezenkimal kök hücrelere farklılaşabildiği gösterilmiştir ${ }^{81}$ Yine benzer bir çalışmada Wanh ve ark ${ }^{82}$ rabittlerin diz ekleminde osteokondral tamir üzerinde matriks sıkılı̆ı̆ın etkilerini göstermiştir. Bu çalışmalar yapı iskelesi mimarisinin ve yapısal özelliklerinin kıkırdak doku mühendisliği için yapı iskelesi dizaynında önemli bir parametre olduğunu göstermiştir. Statik hidrostatik basınçın kollojen yapının artmasını sağladığı ve yapının mekaniksel bütünlüğünü artırdığı ve kondiler doku mühendisliği için faydalı bir uygulama olduğu gösterilmiştir. ${ }^{83,84}$ Weng ve ark. $^{85}$ kondilini elde etmek amacıyla yaptıkları çalışmalarında, insan kondili şekli verilmiş homojen PGA/PLA polimerine sığır periostundan elde ettikleri osteoblast hücrelerini ekleyip, artiküler yüzeylere de aynı hayvandan elde ettikleri kondrositleri ilave etmişler ve bu yapıyı farelerdeki subkütan ceplere yerleştirmişlerdir. 12 haftanın sonunda kondil şeklindeki yapının mikroskobik olarak artiküler yüzeyinde hyalin kıkırdak ile trabeküler kemik oluşumu izlenmiştir. Bu çalışmanın önemi farkılıaşmış otoloj hücreler kulanılarak 2 tabakalı formda mandibuler kondil doku mühendisliği yaratılabileceğinin gösterilmesidir. Abukawa ve ark. ${ }^{86}$ domuz kemik iliğinden elde ettikleri hücreleri, kültür işlemleri ile çoğaltıp domuz kondili şeklini verdikleri polilaktik glikolik asit polimerine ekleyerek implante etmişler ve 6 hafta sonra kondile benzeyen ve histolojik incelemelerde kemik dokusu içeren bir yapı elde etmişlerdir. Benzer çalışmalar Chen ve ark. $^{87,88}$ kondil şeklindeki yapı iskelesinde yeni kemik oluşumu gösterildi. Bu çalışmaların önemi orijinal şekilde üç boyutlu elde edilen yapı iskelelerinde osteogenezisin olabildiğini ortaya çıkarmış olmasıdır. Ueki ve ark. ${ }^{89}$ PLGA ve PGS tavşanlarda kondilektomiyi takiben implante edilmiş ve 24 hafta sonunda kemik ve kıkırdak benzeri dokuların büyüdüğünü gözlemlemişlerdir. Doku rejenerasyonunu artırmak için implantasyondan önce mezenkimal kök hücreler ile PGS ekilmesi önerilmiştir. Bu çalışma PGS nin TME disk doku mühendisliği için iyi bir aday olduğunu göstermiştir. Sonraki çalışmalar osteokondral yapı iskelelerin gelişimi ve yeni hücre kaynaklarının araştırılması üzerine yoğunlaşmıştır. Osteojenik hücreler ve kondrojenik kaynaklı kemik iliği hücrelerinin kullanımı ile insan mandibuler kondilinin şeklinin elde edilmesinin mandibuler kondil mühendisliğinin mümkün olabileceği gösterilmiştir ${ }^{90,91,92}$ Yeni yapı iskelelerin gelişimi ile birlikte, spesifik fiziksel ve mekanik özellikler ile kraniofacial kompozitler ve dizayn için görüntü lemeye dayalı metotlar tanıtıldı. ${ }^{79,} 80,93,94$ ve bu teknikler ile hem hastaya özel spesifik şekil ve poröziteyi hem de arzu edilen elastiklik geçirgenlik sağlanabilir. Selektif lazer sinter metodu ile mandibular kondil şeklinde trabeküler kemiğe benzer mekanik özellikler başarıyla kullanılmıştır. Komputerize tomografi, manyetik rezonans veya CAD-CAM esaslı dizayn yaklaşımları 3 boyutlu yazıım teknikleriyle birleştirilerek spesifik anatomik şekillerde implantlar elde edilmiştir. ${ }^{95,96}$

\section{SONUÇ}

Günümüzde TME doku mühendisliği uygulamaları henüz klinik uygulamalar arasına girememiştir. Tedavi protokolleri arasında yer alabilmesi için çok sayıda araştırmaya gerek duyulmaktadır ve gelecekte kullanılabilecek gibi görünmektedir .

\section{KAYNAKLAR}

1. Sancho-Tello M, Forriol F, Gastaldi P, Ruiz-Saurí A, Martín de Llano JJ, Novella-Maestre E, AntolinosTurpín CM, Gómez-Tejedor JA, Gómez Ribelles JL, Carda C. Time evolution of in vivo articular cartilage repair induced by bone marrow stimulation and scaffold implantation in rabbits. Int J Artif Organs 2015; 38: 210-23

2.Okeson JP. Management of Temporomandibular Disorders and Occlusion. 7th edition. Elsevier Mosby, St Louis, 2013. P. 5,6. 
3. Langer R. Tissue engineering: a new field and its challenges. Pharm Res 1997;14:840-1.

4.Jerjes W, Upile $T$, Abbas $S$, Kafas $P$, Vourvachis $M$, Rob J, Mc Carthy E, Angouridakis N, Hopper C Muscle disorders and dentition-related aspects in temporomandibular disorders: controversies in the most commonly used treatment modalities. Int Arch Med 2008;30:1-23

5. LeResche, L. Epidemiology of temporomandibular disorders: implications for the investigation of etiologic factors. Critical Reviews in Oral Biology \& Medicine 1997;8:291-305.

6. Klausner, JJ. Epidemiologic studies reveal trends in temporomandibular pain and dysfunction. J Mass Dent Soc 1995;44:21-5.

7. Srivastava R, Iyoti $B$, Devi P. Oral splint for temporomandibular joint disorders with revoluationary fluid system. Dent Res J 2013;10:307-13.

8. Long X, Chen G, Cheng AH, Cheng Y, Deng M, Cai $\mathrm{H}$, Meng QA randomized controlled trial of superior and inferior temporomandibular joint space injection with hyaluronic acid in treatment of anterior disc displacement without reduction. J Oral Maxillofac Surg 2009; 67 357-61.

9. Agus B, Weisberg J, Friedman MH. Therapeutic injection of the temporomandibular joint. Oral Surg Oral Med Oral Pathol 1983;55:553-5.

10. Anitua E, Prado R, Orive G. Bilateral sinus elevation evaluating plasma rich in growth factors technology: a report of five cases. Clin Implant Dent Relat Res 2012;14:51-60.

11. Bailey MM, Wang L, Bode CJ, Mitchell KE, Detamore MS. A comparison of human umbilical cord matrix stem cells and temporomandibular joint condylar chondrocytes for tissue engineering temporomandibular joint condylar cartilage. Tissue Eng 2007; 13:2003-2010.

12. Wang L, Lazebnik M, Detamore MS. Hyaline cartilage cells outperform mandibular condylar cartilage cells in a TMJ fibrocartilage tissue engineering application. Osteoarthritis Cartilage 2009;17:346-53.

13. Murphy MK, MacBarb RF, Wong ME, Athanasiou KA. Temporomandibular disorders: a review of etiology, clinical management, and tissue engineering strategies. Int J Oral Maxillofac Implants 2012;28: e393-e414.
14. Thomas M, Grande D, Haug RH. Development of an in vitro temporomandibular joint cartilage analog. J Oral Maxillofac Surg 1991;49:854-6, discussion 857.

15. Puelacher WC, Wisser J, Vacanti CA, Ferraro NF, Jaramillo $D$, Vacanti JP. Temporomandibular joint disc replacement made by tissue-engineered growth of cartilage. J Oral Maxillofac Surg 1994;52:1172-7, discussion 1177-8.

16. Detamore MS, Hegde JN, Wagle RR, Almarza AJ, Montufar-Solis D, Duke PJ, Athanasiou KA. Cell type and distribution in the porcine temporomandibular joint disc. J Oral Maxillofac Surg 2006;64:243-8.

17. Springer IN, Fleiner $B$, Jepsen $S$, Açil $Y$. Culture of cells gained from temporomandibular joint cartilage on non-absorbable scaffolds. Biomaterials 2001;22:2569-77.

18. Johns $D E$, Athanasiou KA. Improving culture conditions for temporomandibular joint disc tissue engineering. Cells Tissues Organs 2007;185:24657.

19. Almarza AJ, Athanasiou KA. Seeding techniques and scaffolding choice for tissue engineering of the temporomandibular joint disk. Tissue Eng 2004;10:1787-95.

20. Almarza AJ, Athanasiou KA. Effects of initial cell seeding density for the tissue engineering of the temporomandibular joint disc. Ann Biomed Eng 2005;33:943-50.

21. Allen KD, Athanasiou KA. Growth factor effects on passaged TMJ disk cells in monolayer and pellet cultures. Orthod Craniofacial Res 2006;9:143-52.

22. Allen KD, Athanasiou KA. Scaffold and Growth Factor Selection in Temporomandibular Joint Disc Engineering. J Dent Res 2008;87:180-5.

23. Anderson DE, Athanasiou KA. A comparison of primary and passaged chondrocytes for use in engineering the temporomandibular joint. Arch Oral Biol 2009;54:138-45.

24. Anderson DE, Athanasiou KA. Passaged costal chondrocytes provide a viable cell source for temporomandibular joint tissue engineering. Ann Biomed Eng 2008;36:1992-2001.

25. Johns DE, Athanasiou KA. Growth factor effects on costal chondrocytes for tissue engineering fibrocartilage. Cell Tissue Res 2008; 333:439-47. 
26. Landesberg R, Takeuchi E, Puzas JE. Cellular, biochemical and molecular characterization of the bovine temporomandibular joint disc. Arch Oral Biol 1996;41:761-7.

27. Allen KD, Athanasiou KA. Effect of passage and topography on gene expression of temporomandibular joint disc cells. Tissue Eng 2007; 13:101-10.

28. Johns DE, Wong ME, Athanasiou KA. ClinicallyRelevant Cell Sources for TMJ Disc Engineering. J Dent Res 2008;87:548-52.

29. Sanchez-Adams J, Athanasiou KA. Dermis isolated adult stem cells for cartilage tissue engineering. Biomaterials 2012;33:109-19.

30. Ahtiainen $\mathrm{K}^{1}$, Mauno J, Ellä $\mathrm{V}$, Hagström J, Lindqvist C, Miettinen S, Ylikomi T, Kellomäki M, Seppänen R. Autologous adipose stem cells and polylactide discs in the replacement of the rabbit temporomandibular joint disc. J R Soc Interface doi: 10.1098/rsif.2013.0287

31. An C, Cheng Y, Yuan Q, Li J. IGF-1 and BMP-2 induces differentiation of adipose-derived mesenchymal stem cells into chondrocytes- like cells. Ann Biomed Eng 2010;38:1647-54.

32. Diekman BO, Rowland CR, Lennon DP, Caplan AI, Guilak F. Chondrogenesis of adult stem cells from adipose tissue and bone marrow: Induction by growth factors and cartilage derived matrix. Tissue Eng Part A 2010;16:523-33.

33. Nerurkar NL, Han W, Mauck RL, Elliott DM. Homologous structure- function relationships between native fibrocartilage and tissue engineered from MSC-seeded nanofibrous Scaffolds. Biomaterials 2011;32:461-8.

34. Connelly JT, Vanderploeg EJ, Mouw JK, Wilson CG, Levenston ME. Tensile Loading Modulates Bone Marrow Stromal Cell Differentiation and the Development of Engineered Fibrocartilage Constructs. Tissue Eng 2010;16:1913-1923.

35. Dickhut A, Dexheimer V, Martin K, Lauinger R, Heisel C, Richter W. Chondrogenesis of human mesenchymal stem cells by local TGF-beta delivery in a biphasic resorbable carrier. Tissue Eng Part A 2010;16:453-64.

36. Hoben GM, Willard VP, Athanasiou KA. Fibrochondrogenesis of hESCs: Growth Factor Combinations and Cocultures. Stem Cells Dev 2009;18:283-292.
37. Koay EJ, Athanasiou KA. Development of SerumFree, Chemically Defined Conditions for Human Embryonic Stem Cell-Derived Fibrochondrogenesis. Tissue Eng 2009;15:2249-57.

38. Ünsal G, Özmekik Ö, Ulukapı I. Dental Kök Hücreler Ve Süt Dişlerinin Kök Hücre Çalışmalarındaki Önemi . Atatürk Üniv Diş Hek Fak Derg 2014; Supplement: 8: 98-106.

39. Wang L, Seshareddy K, Weiss ML, Detamore MS. Effect of Initial Seeding Density on Human Umbilical Cord Mesenchymal Stromal Cells for Fibrocartilage Tissue Engineering. Tissue Eng 2009;15:1009-17.

40. Warnock JJ, Fox DB, Stoker AM, Cook JL. Evaluation of in vitro growth factor treatments on fibrochondrogenesis by synovial membrane cells from osteoarthritic and nonosteoarthritic joints of dogs. Am J Vet Res 2011;72:500-11.

41. Wu Y, Gong Z, Li J, Meng Q, Fang W, Long X. The Pilot Study of Fibrin with Temporomandibular Joint Derived Synovial Stem Cells in Repairing TMJ Disc Perforation. Biomed Res Int doi: $10.1155 / 2014 / 454021$.

42. Semb H. Human embryonic stem cells: origin, properties and applications. APMIS 2005;113:74350.

43. Felka T, Schäfer R, Schewe B, Benz K, Aicher WK. Hypoxia reduces the inhibitory effect of IL-1beta on chondrogenic differentiation of FCS-free expanded MSC. Osteoarthritis Cartilage 2009; 17: 1368-76.

44. Koay EJ, Athanasiou KA. Hypoxic chondrogenic differentiation of human embryonic stem cells enhances cartilage protein synthesis and biomechanical functionality. Osteoarthritis Cartilage 2008; 16:1450-6.

45. Zhang J, Guo F, Mi J, Zhang Z. Periodontal ligamentmesenchymal stromal cells increase proliferation and glycosaminoglycans formation of temporomandibular joint derived fibrochondrocytes. Biomed Res Int doi: $10.1155 / 2014 / 410167$

46. Chen K, Man C, Zhang B, Hu J, Zhu SS. Effect of in vitro chondrogenic differentiation of autologous mesenchymal stemcells on cartilage and subchondral cancellous bone repair in osteoarthritis of temporomandibular joint. Int ] Oral Maxillofac Surg 2013;42, 240-8. 
47. Zheng $Y H$, Su K, Jian $Y T$, Kuang $S$ J, Zhang Z G. Basic fibroblast growth factor enhances osteogenic and chondrogenic differentiation of human bone marrow mesenchymal stem cells in coral scaffold constructs. J Tissue Eng Regen Med 2011;5, 54050

48. Gao Y, Bai C, Xiong H, Li Q, Shan Z, Huang L, Ma $Y$, Guan W. Isolation and characterization of chicken dermis-derived mesenchymal stem/progenitor cells. Biomed Res Int doi.org/ $10.1155 / 2013 / 626258$

49. Cao B, Zheng B, Jankowski RJ, Kimura S, Ikezawa M, Deasy B, Cummins J, Epperly M, Qu-Petersen $Z$, Huard J. Muscle stem cells differentiate into haematopoietic lineages but retain myogenic potential. Nature Cell Biology, 2003;5:640-6.

50. Wu L, Cai X, Zhang S, Karperien M, Lin Y. Regeneration of articular cartilage by adipose tissue derived mesenchymal stem cells: perspectives from stem cell biology and molecular medicine. J Cell Physiol 2013; 228: 938-44.

51. Fu W L, Zhou CY, Yu JK. A new source of mesenchymal stem cells for articular cartilage repair: MSCs derived From mobilized peripheral blood share similar biological characteristics in vitro and chondrogenesis in vivo as MSCs from bone marrow in a rabbit odel. Am J Sports Med 2014;42; 592-601

52. Jones BA, Pei M. Synovium-derived stem cells: a tissue-specific stem cell for cartilage engineering and regeneration. Tissue Eng Part B Rev 2012;18:301-11.

53. Koyama N, Okubo Y, Nakao K, Osawa K, Fujimura, $\mathrm{K}$, Bessho K. Pluripotency of mesenchymal cells derived from synovial fluid in patients with temporomandibular joint disorder. Life Sci 2011;89:7417-47.

54. Liu Z, Long X, Li J, Wei L, Gong Z, Fang W. Differentiation of temporomandibular joint synovial mesenchymal stem cells into neuronal cells in vitro: an in vitro study. Cell Biol Int 2011;35: 8791.

55. Sun Y. PZheng Y H, Liu WJ, Zheng, YL, Zhang ZG. Synovium fragment-derived cells exhibit characteristics similar to those of dissociated multipotent cells in synovial fluid of the temporomandibular joint. PLoS ONE 2014:9: e101896
56. Pei M, He F, Boyce BM, Kish VL. Repair of fullthickness femoral condyle cartilage defects using allogeneic synovial cell-engineered tissue constructs. Osteoarthritis Cartilage 2009;17:71422.

57. Tay AG, Farhadi J, Suetterlin R, Pierer G, Heberer $M$, Martin I. Cell yield, proliferation, and postexpansion differentiation capacity of human ear, nasal, and rib chondrocytes. Tissue Eng 2004;10:762-770.

58. Tan SL, Ahmad TS, Selvaratnam L, Kamarul T. Isolation, characterization and the multi-lineage differentiation potential of rabbit bone marrowderived mesenchymal stem cells. J Anat 2013;222:437-50.

59. Brown BN ${ }^{1}$, Chung WL, Pavlick M, Reppas S, Ochs MW, Russell AJ, Badylak SF. Extracellular matrix as an inductive template for temporomandibular joint meniscus reconstruction: a pilot study. J Oral Maxillofac Surg 2011;69:e488-505.

60. Brown $\mathrm{BN}^{1}$, Chung $\mathrm{WL}$, Almarza AJ, Pavlick MD, Reppas SN, Ochs MW, Russell AJ, Badylak SF. An Inductive, Scaffold-Based, Regenerative Medicine Approach to Reconstruction of the Temporomandibular Joint Disk. J Oral Maxillofac Surg 2012;70:2656-68.

61. Makris EA, Hadidi P, Athanasiou KA. The knee meniscus: structure- function, pathophysiology, current repair techniques, and prospects for regeneration. Biomaterials 2011;32:7411-31

62. Hagandora CK, Gao J, Wang Y, Almarza AJ. Poly (Glycerol Sebacate): A Novel Scaffold Material for Temporomandibular Joint Disc Engineering. Tissue Eng Part A 2013;19:729-37.

63. Petrovic V, Zivkovic P, Petrovic D, Stefanovic V. Craniofacial bone tissue engineering. Oral Surg Oral Med Oral Pathol Oral Radiol 2012;114, e1e9.

64. Toh WS, Spector M, Lee EH, Cao T. Biomaterialmediated delivery of microenvironmental cues for repair and regeneration of articular cartilage. Mol Pharm 2011; 8:994-1001.

65. Allen, KD, Athanasiou, KA. Tissue engineering of the TMJ disc: a review. Tissue Eng 2006;12:118396. 
66. Wong ML, Wong JL, Athanasiou KA, Griffiths LG. Stepwise solubilization-based antigen removal for xenogeneic scaffold generation in tissue engineering. Acta Biomater 2013;9:6492-501.

67. Hu JC, Athanasiou KA. A self-assembling process in articular cartilage tissue engineering. Tissue Eng 2006;12:969-79.

68. Hoenig $E^{1}$, Winkler $T$, Mielke $G$, Paetzold $H$, Schuettler D, Goepfert C, Machens HG, Morlock MM, Schilling AF. High amplitude direct compressive strain enhances mechanical properties of scaffoldfree tissue-engineered cartilage. Tissue Eng Part A 2011;17:1401-11.

69. Athanasiou KA, Eswaramoorthy R, Hadidi P, Hu JC. Self-Organization and the Self-Assembling Process in Tissue Eng. Annu Rev Biomed Eng 2013;15:11536.

70. Hagandora CK, Tudares MA, Almarza AJ. The effect of magnesiumion concentration on the fibrocartilage regeneration potential of goat costal chondrocytes. Ann Biomed Eng 2012;40: 688-696.

71. Kalpakci KN, Willard VP, Wong ME, Athanasiou KA. An interspecies comparison of the temporomandibular joint disc. J Dent Res 2011; 90: 193-8.

72. Cuevas P, Burgos J, Baird A. Basic fibroblast growth factor (FGF) promotes cartilage repair in vivo. Biochem Biophys Res Commun 1988; 156: 611-8.

73. Kyle D. Allen And Kyriacos A. Athanasıou . Tissue Engineering Of The TMJ Disc: A Review. Tissue Eng 2006;12:1183-96.

74. Elder BD, Athanasiou KA. Effects of temporal hydrostatic pressure on tissue-engineered bovine articular cartilage constructs. Tissue Eng Part A 2009; 15:1151-8.

75. Gunja NJ, Athanasiou KA. Effects of hydrostatic pressure on leporine meniscus cell-seeded PLLA scaffolds. J Biomed Mater Res A. 2010,92:896-905.

76. MacBarb RF, Chen AL, Hu JC, Athanasiou KA. Engineering functional anisotropy in fibrocartilage neotissues. Biomaterials 2013;34:9980-9.

77. Gunja NJ, Athanasiou KA. Additive and synergistic effects of bFGF and hypoxia on leporine meniscus cell-seeded PLLA scaffolds. J Tissue Eng Regen Med 2010;4:115-22.
78. Huey DJ, Athanasiou KA. Tension-Compression Loading with Chemical Stimulation Results in Additive Increases to Functional Properties of Anatomic Meniscal Constructs. PLoS One. 2011; 6:e27857.

79. Schek RM, Taboas JM, Hollister SJ, Krebsbach $\mathrm{PH}$. Tissue engineering osteochondral implants for temporomandibular joint repair. Orthod Craniofac Res 2005;8: 313-9.

80. Schek RM, Taboas JM, Segvich SJ, Hollister SJ, Krebsbach $\mathrm{PH}$. Engineered osteochondral grafts using biphasic composite solid free-form fabricated scaffolds. Tissue Engi 2004;10:1376-85.

81. Toh WS, Lim TC, Kurisawa $M$, Spector $M$. Modulation of mesenchymal stem cell chondrogenesis in a tunable hyaluronic acid hydrogel microenvironment. Biomaterials 2012;33: 3835-45.

82. Wang L S, Du C, Toh W S, Wan AC, Gao S J, Kurisawa M. Modulation of chondrocyte functions and stiffness-dependent cartilage repair using an injectable enzymatically crosslinked hydrogel with tunable mechanical properties. Biomaterials 2014;35:2207-2217.

83. Nicodemus GD, Villanueva I, Bryant SJ. Mechanical stimulation of TMJ condylar chondrocytes encapsulated in PEG hydrogels. J Biomed Mater Res A 2007; 83:323-31.

84. Almarza AJ, Athanasiou KA. Effects of hydrostatic pressure on TMJ disc cells. Tissue Eng 2006; 12:1285-94.

85. Weng Y, Cao Y, Silva CA, Vacanti MP, Vacanti CA. Tissue-engineered composites of bone and cartilage for mandible condylar reconstruction. ] Oral Maxillofac Surg 200;59,:185-90.

86. Abukawa $H$, Terai $H$, Hannouche D, Vacanti JP, Kaban LB, Troulis MJ Formation of a mandibular condyle in vitro by tissue engineering. J Oral Maxillofac Surg 2003;61:94-100.

87. Chen F, Mao T, Tao K, Chen S, Ding G, Gu X. Bone graft in the shape of human mandibular condyle reconstruction via seeding marrow-derived osteoblasts into porous coral in a nude mice model. J Oral Maxillofac Surg 2002;60:1155-9.

88. Chen F, Chen S, Tao K, Feng X, Liu Y. Lei D, Mao T. Marrow-derived osteoblasts seeded into porous natural coral to prefabricate a vascularised bone graft in the shape of a human mandibular ramus: 
experimental study in rabbits. $\mathrm{Br} \mathrm{J}$ Oral Maxillofac Surg 2004;42:532-7.

89. Ueki K, Takazakura D, Marukawa K, Shimada M, Nakagawa K, Takatsuka S, Yamamoto E. The use of polylactic acid/polyglycolic acid copolymer and gelatin sponge complex containing human recombinant bone morphogenetic protein-2 following condylectomy in rabbits. J Craniomaxillofac Surg 2003;31:107-14.

90. Mao JJ. Stem-cell-driven regeneration of synovial joints. Biol Cell 2005;97:289-301.

91. Alhadlaq A, Mao JJ. Mesenchymal stem cells: isolation and therapeutics. Stem Cells Dev 2004;13:436-48.

92. Alhadlaq A, Mao, JJ. Tissue-engineered osteochondral constructs in the shape of an articular condyle. J Bone Joint Surg Am 2005;87: 936-44.

93. Williams JM, Adewunmi A, Schek RM, Flanagan CL, Krebsbach PH, Feinberg SE, Hollister SJ, Das S. Bone tissue engineering using polycaprolactone scaffolds fabricated via selective laser sintering. Biomaterials 2005 Aug;26:4817-27.

94. Schek RM, Taboas JM, Hollister SJ, Krebsbach PH. Tissue engineering osteochondral implants for temporomandibular joint repair. Orthod Craniofac Res 2005;8:313-9.

95. Ciocca L, Donati D, Ragazzini S, Dozza B, Rossi F, Fantini M, Spadari A, Romagnoli N, Landi E, Tampieri A, Piattelli A, Iezzi G, Scotti Mesenchymal stem cells and platelet gel improve bone deposition within CAD-CAM custom-made ceramic HA scaffolds for condyle substitution. BioMedicine Research International doi: 10.1155/2013/549762.

96. Mao, JJ, Giannobile WV, Helms JA, Hollister SJ, Krebsbach PH, Longaker MT, S Shi. Craniofacial tissue engineering by stem cells. J Dent Res 2006;85: 966-79.

\section{Yazışma Adresi}

Doç. Dr Perihan OYAR

Hacettepe Üniversitesi

Sağlık Hizmetleri Meslek Yüksek Okulu, DişProtez Teknolojisi Programı,

D-Blok, 3. Kat, 06100 Sihhıye-Ankara / TÜRKİYE,

Fax: +90-312-3102730,

telefon: +90-312-305 1587 / 111, 130

e-mail: poyar73@gmail.com 